\title{
Target Setting to Reduce Infant Mortality Across Indian States: A Statistical Approach
}

\section{Ananya Mishra* and Arvind Narayan Mishra}

Prag Narain Road, Lucknow-226001, Uttar Pradesh, India

*Corresponding author: ananya123mishra@gmail.com

\begin{abstract}
Background: An important area in healthcare policy is Child survival. The metric for Child survival is Infant Mortality Rate. As a country, India has registered significant decline in Infant Mortality Rate, however, the progress of individual States have varied, with many well performing and various laggard States. States are important units for healthcare policy since the subject of health comes under the State List in the Constitution; therefore implementation of interventions is the responsibility of the State. This paper therefore seeks to develop a Statistical model to estimate Infant Mortality Rate and set targets based on the factors that determine the predictive model.

Methodology: Infant Mortality Rate for different States were regressed against relevant healthcare service delivery metrics, quality of infrastructure metrics, socio-economic factors as recorded in National Family Health Survey 4 (2015-16). A multivariate model was developed estimating IMR at given values of operational factors. For policy target setting, States were clustered on the basis of Infant Mortality Rates and target for each cluster was defined in terms of factors and in turn, a target IMR value for different clusters were derived.

Results: The result demonstrate that the Infant Mortality Rate levels for reference year 2015-16 had a significant relationship with "Percentage of women with mobile phone" and "Percentage of women who received at least four Antenatal Care visits during their pregnancy". The second metric as a proxy for gender development had a higher beta coefficient than the first metric, a proxy for health infrastructure.

Conclusion: Improving the metric for institutional birth percentage, registration of pregnancies and using technology to follow up and manage data on pregnancies are important. The second factor highlights the convergence of development outcomes that is, lower IMR with higher agency (higher literacy and access to technology) and development of infrastructure (increased mobile penetration). Therefore, for gender development indicator, access to technology, internet penetration, digital literacy and incentivizing higher agency to women of the household are recommended.
\end{abstract}

Keywords: Infant Mortality Rate, Child Survival, Reproductive and Child Healthcare, Antenatal Care and Gender Development.

Infant Mortality Rate is a key indicator for measuring child mortality and morbidity levels. It is indicative of quality of infrastructure, social and behavioral factors and level of development of a country.

As per World Health Indicator (WHO), Infant mortality rate is the probability of a child born in a specific year or period dying before reaching the age of one, if subject to age-specific mortality rates of that period. Infant mortality rate is strictly speaking not a rate (i.e. the number of deaths divided by the number of population at risk during a certain period of time) but a probability of death derived from a life table and expressed as rate per 1000 live births. Infant mortality represents an important component of under-five mortality, measuring 
child survival. They also reflect the social, economic and environmental conditions in which children (and others in society) live, including their health care. Since data on the incidence and prevalence of diseases (morbidity data) frequently are unavailable, mortality rates are often used to identify vulnerable populations. Infant mortality rate was an MDG indicator ${ }^{1}$.

While, Infant Mortality Rate has not been a specific target under Sustainable Development Goals, it captures the state of affairs of Maternal Healthcare available in the country very well. At national policy level, its relevance is underscored by the fact that National Government of India has included Infant Mortality Rate as a policy target under National Health Policy 2017. The National Health Policy had set the target for Infant Mortality Rate at 28 by $2019^{2}$.

As per Sample Registration System Bulletin released in May 20203, the national upper and lower limit of Infant Mortality for the year 2018 is estimated to be 32 . Considering the decadal decline and the fact that at lower levels of Infant Mortality Rate, it will get tougher to register further decline, there is a strong likelihood that we may miss our targets for surveys conducted in 2019, although not by a large margin. Moreover, even if the target is achieved, the targets for next 5 years have to be laid down.

This paper aims to establish concrete goals and development indicators which are not only focus on healthcare but also socioeconomic in nature, that can reduce Infant Mortality Rate levels for the governments to pursue, especially considering the country is at the last stretch to achieve national targets. Such goals would be based on extensive study of the data in National Family Health Survey-4 (2015-16). The paper identifies the factors that affect the levels of Infant Mortality Rate across State, classifies the States into 4 clusters based on their achievement of targets and calculate optimal levels of each factor required for States in different cluster.

The model although is based on national data, sets targets for different clusters of states, therefore ensuring that the model doesn't present rigidities to the States and prevents the classical 'one size fits all' approach, especially considering that Health being a state subject, its operational efficiency varies across States and even district to district.

The model is based on socio-economic factors such as gender development and access to technology which therefore, allows the paper to also focus on policy convergence between gender development, access to technology and reducing Infant Mortality Rate, which in turn allows the focus to shift on Sustainable Development Goals and broader indicators for similar developing countries to reduce Infant Mortality Rate.

\section{METHODOLOGY}

The study is broken into three parts:

1. Identifying the significant operational indicators for estimating Infant Mortality Rate: The values of Infant Mortality Rate and other indicators were based on the National Family Health Survey 4, 2015-16 by Ministry of Health and Family Welfare, Government of India. For identifying the operational indicators, regression analysis for the dataset was conducted. The values of $\mathrm{R}^{2}$ and $\mathrm{p}$-values were checked for significance. Based on regression analysis a multivariate model estimating Infant Mortality Rate was determined with reasonable statistical significance.

Multiple regression model is then tested for distortions suchasmulticollinearityand heteroscedasticity toprevent results being obscured by interplay of independent variables. Test for identifying multicollinearity is determining the correlation levels amongst the independent variables. For heteroscedasticity, Bruesch Pagan Test was conducted on the model. The analysis was conducted using Microsoft Excel

The relevance of the operational indicators with respect to other social indicators like health infrastructure, gender development is determined based on correlation between them.

\section{Clustering the States into four categories based on} their Infant Mortality Rate: Using the K-Mean method of clustering, clustering States on the basis of Infant Mortality Rate and not on the basis of region. Regional Classification has been the norm for policy planning, but such classification does not take into account intra- 
regional variations. For example, in the Northeastern part of India the variations in Infant Mortality Rate recorded seem to suggest wide intra-region variations.

The states were classified in four clusters. The clusters are based on the classification criteria used by NITI Aayog in Sustainable Development Goals India Index ${ }^{4}$. The criterion in the clusters is Infant Mortality Rate instead of an index since the model sets target based on Infant Mortality Rate:

* Achiever: The States that have achieved Infant Mortality Rate rates well below the national targets (28) and are focusing on reducing the Infant Mortality Rate numbers at very low values below 20 to single digits. For this targeted interventions, last mile connectivity and Information Education and Communication drives are crucial. This cluster only includes two states: Kerala and Goa

* Frontrunner: States that have Infant Mortality Rate levels between 15-30 that have just or are going to achieve the national target are the frontrunners. Such states have significantly improved infrastructure and reproductive and child healthcare indicators and look to develop further on existing momentum. This group contains the most states including industrialized states such as Tamil Nadu, Maharashtra and Karnataka, Information Technology hub Telangana and also 6 out of the 8 Northeast States, apart from Punjab and West Bengal

- Performer: States that have Infant Mortality Rate levels ranging from 30 to 45 . This cluster includes 10 states, which include states Empowered Action Group States like Odisha and Rajasthan that have registered improvements in Reproductive and Child Health indicators, hilly states of Western Himalayas: Jammu and Kashmir (erstwhile State), Uttarakhand and Himachal Pradesh. These States have improved significantly, with States like Odisha reducing Infant Mortality Rate levels from 68 to 40 in over a decade. Rajasthan also has improved drastically; to the extent that the then Niti Aayog Vice Chairperson Arvind
Panagariya is quoted to have said Rajasthan is no longer BIMARU in $2015^{5}$.

* Aspirant: Aspirant States include States having Infant Mortality Rate levels more than 45. Such states include Effective Action Group states like Bihar, Chhattisgarh, Madhya Pradesh and Uttar Pradesh and also Assam. Such states have the highest scope of improvement and the steepest targets.

3. Setting fixed targets for operational factors and estimating the targeted Infant Mortality Rate levels. After clustering the states, the next part of the study is to focus on specific operational targets to achieve lower Infant Mortality Rate levels. Based on the targets for the operational factors, final Infant Mortality Rate targets for States in different clusters are determined.

Every cluster was clubbed with all the clusters that had better Infant Mortality Rate mean. Cut off percentile for each cumulative arrays of factors were determined. The cutoff for individual factors became the target for the particular cluster. As we moved to clusters having lower value, the cut off percentile was dropped by 15 points to set a realistic target. For example, we took the cluster of 'Achiever' State with the 'Front Runner' States and then determined the $90^{\text {th }}$ Percentile of the factors to determine the targets for each factor.

Such targets then can be used as indicators for predicting levels of Infant Mortality Rate, and for focusing on policy corrections to achieve targets.

For target setting, the following criteria are developed:

Table 1: Methodology for targets of different clusters of States

\begin{tabular}{|c|l|l|}
\hline S1. No. & Cluster & Methodology \\
\hline 1 & Performer State & No targets recommended \\
\hline 2 & $\begin{array}{l}\text { Front Runner } \\
\text { States }\end{array}$ & $\begin{array}{l}\text { The } 90^{\text {th }} \text { Quartile of the indicators } \\
\text { amongst all states in the cluster } 1 \text { and } 2\end{array}$ \\
\hline 3 & Performer State & $\begin{array}{l}\text { The } 75^{\text {th }} \text { Percentile of all indicators } \\
\text { from all states in cluster 1,2 and 3 } \\
\text { combined }\end{array}$ \\
\hline 4 & Aspirant State & $\begin{array}{l}\text { The } 60^{\text {th }} \text { percentile of all indicators } \\
\text { from states in clusters } 1,2,3 \text { and } 4 \\
\text { combined. }\end{array}$ \\
\hline
\end{tabular}


Based on the above criteria targets for factors are determined, and targeted Infant Mortality Rate is estimated.

\section{(I) Factors for Estimating Infant Mortality Rate}

The strength of the relationship between indicators of the aforementioned factors and Infant Mortality Rates were determined based on regression between the factor (independent variables) and Infant Mortality Rate (dependent variables). The study covers 29 states; using data from National Family Health Survey IV 2015-16.

The factor wise conclusions from the exercise are summarized below:

1. Institutional Delivery: Institutional Birth means giving birth to a child in a medical institution under overall supervision of trained and competent health personnel where there are more amenities to handle the situation and save the life of mother and child. Institutional delivery is an important component for maternal health care. Non-institutional births are prone to infections from unhygienic or lack of hygienic measures in place and lack of expertise in handling complications related to pregnancy.

Non-Institutional Deliveries as probability of infections, lack of proper health care services increases risk of mortality.

The indicators related to institutional delivery are described below:

(i) Percentage of Institutional Deliveries: was recorded in National Family Health Survey-4 (2015-16). The association between institutional delivery and Infant Mortality Rate was insignificant as determined by regressing Infant Mortality Rate against Institutional Delivery Percentage (Value of $\mathrm{R}^{2}=0.118$ and p-value $=0.074)$. Therefore, there is no statistically significant relation between institutional birth and Infant Mortality Rate, as per the data at a national level. This variable cannot be used for developing the model. Although, by causality and theoretical principles, there exist a significant relationship between these variables.

(ii) Cost of Institutional Birth (Out of Pocket Expenditure): The cost of institutional birth affects affordability of Institutional Birth. High cost of institutional birth is an indicator of lack of accessibility and affordability of institutional births. Extremely high cost of institutional birth also shows lack of public healthcare centers for institutional birth.

With a view to increase institutional delivery, Government of India launched Janani Suraksha Yojana, a countrywide conditional cash transfer scheme. It integrates cash assistance with post-delivery care.

Study by Mishra S., Mohanty K.S. (2019) found that higher out of pocket expenditure leads to distress financing. This distress financing is prevalent amongst economically weaker sections and vulnerable sections in private health care ${ }^{6}$. It therefore, indicates a disparity between privileged and vulnerable sections of society. Therefore, Out of Pocket expenditure should be reduced by increasing Public Healthcare Facilities, improving availability of medicine and diagnostic services to reduce economic burden due to non-institutional delivery.

Statistically, Out of Pocket expenditure has a significant relationship with Infant Mortality Rate. The p-values are low (0.000692) and the $\mathrm{R}^{2}$ or goodness-of-fit is 35 percent which for a single indicator can be relevant.

However, this indicator cannot be used in the model, because the causality is opposite of that the model seeks. The negative coefficient indicates higher the value of Out of Pocket Expenditure, the lower the Infant Mortality Rate, as we have seen many states like Kerala, Manipur and Odisha which have low Infant Mortality Rate tend to have high Out of Pocket Expenditure, probably owning to lack of public health care expenditure or better developed private health care systems. While many focus states like Uttar Pradesh and Bihar, which have high Infant Mortality Rate owing to being focus states have higher provisioning for schemes like Janani Suraksha Yojana, reducing the Out of Pocket Expenditure. Therefore, the trend and the causality are reversed in the analysis.

(iii) Percentage of Mothers who received Financial Assistance under Janani Suraksha Yojana: Observational Study across India by Gupta, Dinesh, et al. (2012) notes that Conditional Cash transfer has had a positive impact on percentage of institutional delivery 
and other Reproductive and Child Health Indicators associated with it ${ }^{7}$.

Coverage of Financial Assistance under Janani Suraksha Yojana has a significant and relevant relationship with Infant Mortality Rate. The linear regression tests showed reasonable significance ( $p$-values $=2.16 \mathrm{E}-05$ ) and was fairly data descriptive $\left(R^{2}=0.49\right)$. However, again as we see, the Focus states having high Infant Mortality Rate are covered under Janani Suraksha Yojana and have extensive coverage; therefore States with lower Infant Mortality Rate have lower financial assistance under Janani Suraksha Yojana, and Aspirant States like Uttar Pradesh being a focus state has higher financial assistance. This relation therefore is counterintuitive, high Infant Mortality Rate and high Financial Assistance if we see the indicator as a cause of Infant Mortality Rate, but actually the high Infant Mortality Rate is the cause of higher financial assistance.

Therefore, the variable cannot be considered for the model.

The summary of all the aforementioned variables are given below with significance, goodness of fit and usability in the model:

Table 2: Indicators related to Institutional Birth

\begin{tabular}{lllll}
\hline $\begin{array}{l}\text { S1. } \\
\text { No. }\end{array}$ & Indicator & $\begin{array}{l}\mathbf{R}^{2} \\
\text { Value }\end{array}$ & $\begin{array}{l}\text { p- } \\
\text { values }\end{array}$ & $\begin{array}{l}\text { Signifi- } \\
\text { cance }\end{array}$ \\
\hline 1 & $\begin{array}{l}\text { Percentage of Institutional } \\
\text { Deliveries }\end{array}$ & 0.118 & 0.074 & $\begin{array}{l}\text { Insignifi- } \\
\text { cant }\end{array}$ \\
2 & $\begin{array}{l}\text { Cost of Institutional Birth } \\
\text { (Out of Pocket Expenditure) }\end{array}$ & 0.352 & 0.000692 & $\begin{array}{l}\text { Signifi- } \\
\text { cant }\end{array}$ \\
3 & $\begin{array}{l}\text { Percentage of Mothers who } \\
\text { received Financial Assistance } \\
\text { under Janani Suraksha Yojana }\end{array}$ & 0.49 & $2.16 \mathrm{E}-05$ & $\begin{array}{l}\text { Signifi- } \\
\text { cant }\end{array}$ \\
4 & $\begin{array}{l}\text { Percentage of Births assisted } \\
\text { by a doctor/nurse/LHV/ } \\
\text { ANM/ other health personnel }\end{array}$ & 0.108 & 0.081 & $\begin{array}{l}\text { Not Sig- } \\
\text { nificant }\end{array}$ \\
\hline
\end{tabular}

\section{AVAILABILITY OF ANTE-NATAL CARE}

Antenatal Care or prenatal care is the preventive healthcare offered to pregnant women before delivery such as regular check-ups to prevent complications and health problems. The Reproductive and Child Health Program of Government of India (GOI) aims to provide at least four antenatal check-ups which should include a weight and blood pressure check, Laboratory investigations, abdominal examination, immunization against tetanus, iron and folic acid (IFA) prophylaxis, as well as anemia management. (National Family Health Survey - III India Maternal Health, 2005). World Health Organization recommends at least four contacts with a health provider during pregnancy.

Indicators for Antenatal Care mentioned in National Family Health Survey-4 (2015-16) are: (a) 'Percentage of Mothers who had at least 4 Antenatal Care visits' (b) 'Percentage of pregnant women that received all recommended Ante-Natal Care' (c) 'Percentage of Mothers who had antenatal check-up in the first trimester '

Table 3: Indicators for Antenatal Care

\begin{tabular}{|c|c|c|c|c|}
\hline $\begin{array}{l}\text { S1. } \\
\text { No. }\end{array}$ & Indicator & $\begin{array}{l}\mathbf{R}^{2} \\
\text { Value }\end{array}$ & $\begin{array}{l}\mathrm{p}- \\
\text { value }\end{array}$ & $\begin{array}{l}\text { Signifi- } \\
\text { cance }\end{array}$ \\
\hline 1 & $\begin{array}{l}\text { "Percentage of Mothers who } \\
\text { had at least } 4 \text { ANC visits" }\end{array}$ & 0.37 & 0.000465 & $\begin{array}{l}\text { Signifi- } \\
\text { cant }\end{array}$ \\
\hline 2 & $\begin{array}{l}\text { "Percentage of pregnant } \\
\text { women that received all } \\
\text { recommended Ante-Natal } \\
\text { Care" }\end{array}$ & 0.38 & 0.000355 & $\begin{array}{l}\text { Signifi- } \\
\text { cant }\end{array}$ \\
\hline 3 & $\begin{array}{l}\text { "Percentage of Mothers who } \\
\text { had antenatal check-up in the } \\
\text { first trimester" }\end{array}$ & 0.20 & 0.014 & $\begin{array}{l}\text { Not Sig- } \\
\text { nificant }\end{array}$ \\
\hline
\end{tabular}

All the three indicators are statistically significant due to lower p-values. The goodness of fit is low for all the three variables. Antenatal Care may impact the health of the pregnant women and in turn the infant. The variable can be used for building model, as principle of causality is not affected and the results can be significant.

\section{AVAILABILITY OF POST NATAL CARE}

Post-Natal Care interventions are one of the most important institutional supports for reducing child morbidities. Postnatal Care includes the treatment and medical interventions given to pregnant women and infant for first 6 weeks after the delivery. The prenatal care is important for nutritional security and immunization of new born, safety of the mother and ensuring Child survival. 
* The data on Post-Natal checkups for mother were noted under two heads in National Family Health Survey-IV:

* 'Percentage of deliveries with post-natal check for the mother'

* 'Percentage of deliveries with post-natal check for the mother in first two days'.

The regression analysis gave us following results:

Table 4: Indicators for Post Natal Care

\begin{tabular}{|c|c|c|c|c|}
\hline $\begin{array}{l}\text { Sl. } \\
\text { No. }\end{array}$ & Indicator & $\begin{array}{l}\mathbf{R}^{2} \\
\text { Value }\end{array}$ & $\begin{array}{l}p \text { - } \\
\text { values }\end{array}$ & $\begin{array}{l}\text { Signifi- } \\
\text { cance }\end{array}$ \\
\hline 1 & $\begin{array}{l}\text { "Percentage of Children who } \\
\text { received a health check after birth } \\
\text { from a doctor/nurse/LHV/ ANM } \\
\text { / midwife/other health personnel } \\
\text { within } 2 \text { days of birth" }\end{array}$ & 0.069 & 0.168 & $\begin{array}{l}\text { Not Sig- } \\
\text { nificant }\end{array}$ \\
\hline 2 & $\begin{array}{l}\text { "Percentage of Mothers who } \\
\text { received postnatal care from } \\
\text { a doctor/ nurse/LHV/ANM/ } \\
\text { midwife/other health personnel } \\
\text { within } 2 \text { days of delivery" }\end{array}$ & 0.157 & 0.033 & $\begin{array}{l}\text { Signif- } \\
\text { icant; } \\
\text { can be } \\
\text { consid- } \\
\text { ered }\end{array}$ \\
\hline
\end{tabular}

Out of the two postnatal care indicators, 'Percentage of deliveries with post-natal check for the mother' is not displaying significant relationship with Infant Mortality Rate. Also the goodness of fit in the model with significant relationship was low, however, variable 'Percentage of deliveries with post-natal check for the mother in first two days' can be considered for building the model.

Nutrition Levels of Mothers: Nutrition levels of mothers are important to ensure smoother pregnancy and reduce maternal and child mortality. Widespread anemia and deficiency of folic acid are one of the important results of lower nutrition levels. Under National Family Health Survey IV, there are five indicators related to pregnant women's nutrition. Out of 5, only one indicator, mother who consumed iron folic acid for 100 days when pregnant is statistically significant and has marginally high goodness of fit. The value of $R^{2}=0.28$ and $p$-values $=0.0032$. The metric was recorded in National Family Health Survey-IV (2015-16). Therefore, the variable can be incorporated in the model.
Table 5: Indicators related to Maternal Nutrition

\begin{tabular}{|c|c|c|c|c|}
\hline $\begin{array}{l}\text { Sl. } \\
\text { No }\end{array}$ & Indicators & $\begin{array}{l}\mathbf{R}^{2} \\
\text { Value } \\
\end{array}$ & $\begin{array}{l}\mathrm{p} \text { - } \\
\text { value }\end{array}$ & $\begin{array}{l}\text { Signifi- } \\
\text { cance }\end{array}$ \\
\hline 1 & $\begin{array}{l}\text { "Pregnant women age } 15- \\
49 \text { years who are anemic" }\end{array}$ & 0.084 & 0.127 & $\begin{array}{l}\text { Not Sig- } \\
\text { nificant }\end{array}$ \\
\hline 2 & $\begin{array}{l}\text { "Non-pregnant women } \\
\text { age } 15-49 \text { years who are } \\
\text { anemic" }\end{array}$ & 0.009 & 0.623 & $\begin{array}{l}\text { Not Sig- } \\
\text { nificant }\end{array}$ \\
\hline 3 & $\begin{array}{l}\text { "Women whose Body } \\
\text { Mass Index (BMI) is below } \\
\text { normal }\left(\mathrm{BMI}<18.5 \mathrm{~kg} / \mathrm{m}^{2}\right)^{\prime}\end{array}$ & 0.062 & 0.194 & $\begin{array}{l}\text { Not Sig- } \\
\text { nificant }\end{array}$ \\
\hline 4 & $\begin{array}{l}\text { "All women age 15-49 } \\
\text { years who are anemic" }\end{array}$ & 0.0101 & 0.602 & $\begin{array}{l}\text { Not Sig- } \\
\text { nificant }\end{array}$ \\
\hline 5 & $\begin{array}{l}\text { "Percentage of Mothers } \\
\text { who consumed iron folic } \\
\text { acid for } 100 \text { days or more } \\
\text { when they were pregnant" }\end{array}$ & 0.28 & 0.0032 & $\begin{array}{l}\text { Signifi- } \\
\text { cant; can } \\
\text { be con- } \\
\text { sidered }\end{array}$ \\
\hline
\end{tabular}

Levels of Female Empowerment: Better Gender Development Indicators have a significant impact on Reproductive and Child Health Indicators ${ }^{8}$. Indicators of women empowerment that were surveyed in National Family Health Survey 4 were literacy rate, having agency and financial autonomy, in terms of access and control of bank accounts, digital literacy as measured by mobile and participation in decision making powers in households. Such indicators also impact the awareness of women, her access to medical health and therefore also help reduce infant and maternal mortality.

Therefore, social and behavioral factors such following government advisories, and following all aspects of institutional birth are largely attributed to better gender development indicators. In the study, the following indicators were regressed with Infant Mortality Rate to determine linear relationship with it.

Table 6: Indicators related to Gender Development Indicators

\begin{tabular}{lllll}
\hline $\begin{array}{l}\text { S1. } \\
\text { No. }\end{array}$ & Indicator & $\begin{array}{l}\mathbf{R}^{2} \\
\text { Value }\end{array}$ & $\begin{array}{l}\mathbf{p} \text { - } \\
\text { value }\end{array}$ & Result \\
\hline 1 & Female Literacy & 0.42 & 0.00015 & Significant \\
2 & $\begin{array}{l}\text { Percentage of Population } \\
\text { (female) age 6 years or above }\end{array}$ & 0.37 & 0.00048 & $\begin{array}{l}\text { Significant, } \\
\text { low } \\
\text { description }\end{array}$ \\
3 & $\begin{array}{l}\text { Who ever attended school } \\
\text { Women with 10 or more }\end{array}$ & 0.41 & 0.000167 & Significant \\
& years of schooling & & &
\end{tabular}


Currently married women
who participate in household decision

$5 \quad$ Women having mobile phone 0.42 that they use themselves

6 Women having bank account 0.20 that they themselves use

7 Married Women who have 0.06 ever experienced spousal violence

The majority of gender development indicators have high goodness of fit $(>0.30)$ and significant $p$-values. Therefore, these variables can be used in the model.

\section{SUMMARY:}

Significant Indicators among different factors that can be considered for developing the model are:

Table 7: List of Significant Indicators

\begin{tabular}{|c|c|}
\hline S1. No. & Indicator \\
\hline 1. & $\begin{array}{l}\text { "Percentage of Mothers who had at least } 4 \text { ANC } \\
\text { visits" }\end{array}$ \\
\hline 2 & $\begin{array}{l}\text { "Percentage of pregnant women that received all } \\
\text { recommended Ante-Natal Care" }\end{array}$ \\
\hline 3 & $\begin{array}{l}\text { "Percentage of Mothers who received postnatal care } \\
\text { from a doctor/ nurse/LHV/ANM/midwife/other } \\
\text { health personnel within } 2 \text { days of delivery" }\end{array}$ \\
\hline 4 & $\begin{array}{l}\text { "Percentage of Mothers who consumed iron folic } \\
\text { acid for } 100 \text { days or more when they were pregnant" }\end{array}$ \\
\hline 5 & Female Literacy \\
\hline 6 & Women with 10 or more years of schooling \\
\hline 7 & $\begin{array}{l}\text { Women having mobile phone that they use } \\
\text { themselves }\end{array}$ \\
\hline 8 & $\begin{array}{l}\text { Percentage of Population( female) age } 6 \text { years or } \\
\text { above who ever attended school }\end{array}$ \\
\hline
\end{tabular}

\section{QUANTITATIVE RESULTS}

The analysis focused on finding relations and significance of relations between Infant Mortality Rate (2015 levels) and the identified metrics representing different factors. In total, four major variables have shown significant relationship with Infant Mortality Rate, having higher goodness of fit. Two of these, 'financial assistance under
Janani Suraksha Yojana' and 'out of pocket expenditure on institutional delivery' were dropped from the model due to lack of causality.

Table 8: Results of Regression

\begin{tabular}{ll}
\hline \multicolumn{2}{l}{ Regression Statistics } \\
\hline Multiple R & 0.769461 \\
R Square & 0.59207 \\
Adjusted R Square & 0.560691 \\
Standard Error & 8.174506 \\
Observations & 29 \\
\hline
\end{tabular}

\begin{tabular}{|c|c|c|c|c|c|c|}
\hline \multicolumn{7}{|l|}{ ANOVA } \\
\hline & df & SS & MS & $\mathbf{F}$ & \multicolumn{2}{|c|}{ Significance $\mathrm{F}$} \\
\hline Regression & 2 & 2521.648 & 1260.8241 & 18.86824 & $8.66 \mathrm{E}$ & -06 \\
\hline Residual & 26 & 1737.386 & 66.82256 & & & \\
\hline Total & 28 & 4259.034 & & & & \\
\hline & \multicolumn{2}{|c|}{ Coefficientandard Err tStat } & P-value !ower 95\% & 5\% Upper 95\% & wer $95.0 \%$ & Upper $95.0 \%$ \\
\hline Intercept & 68.7357 & 5.97646511 .50106 & $1.07 E-11 \quad 56.4505$ & 0981.0205 & 56.4509 & 81.0204971 \\
\hline Maternity Care (for & r -0.24541 & $\begin{array}{lll}0.074059 & -3.31377\end{array}$ & $0.002713-0.3976$ & $64-0.09318$ & -0.39764 & -0.093184 \\
\hline Women's Empowel & -0.39566 & $0.105148-3.76291$ & $0.000865 \quad-0.6118$ & $18-0.17953$ & -0.6118 & -0.179527888 \\
\hline
\end{tabular}

Standardized Test Results: To determine the relative significance of different variables, regression of standardized variables were undertaken to get beta values indicating the impact different variables had over a standard deviation. The beta coefficients determine the relative significance of the independent variables, by standardizing all the variables- independent and dependent.

\section{Summary Output}

\begin{tabular}{|c|c|c|c|c|c|c|}
\hline \multicolumn{7}{|c|}{ Regression Statistics } \\
\hline \multicolumn{3}{|c|}{ Multiple R } & \multicolumn{4}{|c|}{0.769461} \\
\hline \multicolumn{3}{|l|}{ R Square } & \multicolumn{4}{|c|}{0.59207} \\
\hline \multicolumn{3}{|c|}{ Adjusted R Square } & \multicolumn{4}{|c|}{0.560691} \\
\hline \multicolumn{3}{|c|}{ Standard Error } & \multicolumn{4}{|c|}{0.662804} \\
\hline \multicolumn{3}{|c|}{ Observations } & \multicolumn{4}{|l|}{29} \\
\hline \multicolumn{7}{|l|}{ ANOVA } \\
\hline & df & SS & & MS & $\mathbf{F}$ & Significance F \\
\hline Regression & 2 & 16.5779 & & 3.288985 & 18.868248 & $8.66 \mathrm{E}-06$ \\
\hline Residual & 26 & 11.4220 & 030. & .439309 & & \\
\hline \multirow[t]{2}{*}{ Total } & 28 & 28 & & & & \\
\hline & \multicolumn{2}{|c|}{ Coefficientsandard Err } & tStat & $P$-value Lo & ower 95\%Upper 95\% & $\%$ ower 95.0\%pper 95.0\% \\
\hline Intercept & $-1.5 E-16$ & 0.12308 & $-1.2 E-15$ & 1 & $-0.25299 \quad 0.252994$ & $\begin{array}{lll}34 & -0.25299 & 0.252994\end{array}$ \\
\hline Women's Empc - & -0.50026 & 0.132946 & -3.76291 & 0.000865 & $-0.77354 \quad-0.22699$ & $99-0.77354 \quad-0.22699$ \\
\hline Maternity Care & -0.44055 & 0.132946 & -3.31377 & 0.002713 & $-0.71383-0.16728$ & $\begin{array}{lll}8 & -0.71383 & -0.16728 \\
\end{array}$ \\
\hline
\end{tabular}


Based on this study, the independent variable, a change in which has maximum impact on Infant Mortality Rate are in the following order:

(a) Percentage of women having a mobile phone that they themselves use

(b) Percentage of Mothers who had at least 4 antenatal care visits

\section{MODEL TESTING}

The model was tested for heteroscedasticity and multicollinearity. The two independent variables have a low correlation value (0.335). Therefore there is no multicollinearity between the two independent variables.

For heteroscedasticity, Bruesch Pagan Test was conducted. The square of the residuals of estimates from the model were regressed against the indicators. The value of $R^{2}$ of this regression was used to determine chi-square value for determining the significance of the null hypothesis that there exists heteroscedasticity. The p-values of the chi-square test recorded was way higher than 0.05 (0.207), rejecting the null hypothesis and therefore proving that the data was free from heteroscedasticity.

Therefore, the data is free from distortions and therefore, model is fit for estimation of Infant Mortality Rate

\section{INTERPRETATION}

The two factors are therefore, suitable to be used in development of model to determine forecasts of Infant Mortality Rate levels. Based on the unstandardized regression model we can derive the equation to estimate Infant Mortality Rate.

$$
Y_{i}=68.73-0.245 X_{1 i}-0.396 X_{2 i}
$$

Where,

$$
Y_{i}=\text { Infant Mortality Rate }
$$

$X_{1 i}=$ Percentage of mothers who had at least 4 antenatal care visits

$X_{2 i}=$ Percentage of women having a mobile phone that they themselves use
The assumptions underlying the model are:

1. The model only explains 59 per cent of the Infant Mortality Rate trends, other key factors that may impact the Infant Mortality Rate levels like Institutional delivery, Post Natal Care and Nutrition Levels have not been factored. Such indicators have shown higher degree of correlation with Antenatal Care indicators, but have not shown any significant relationship with Infant Mortality Rate. For accurate estimation, with higher number of variables higher number of observations is required. Since the total observations (29) at subnational level are fixed, the model has to limit to 2 to 3 variables.

2. Moreover, from among all the variables, the aforementioned ones gave the highest value of $R^{2}$ and were statistically significant.

3. The model uses data from across the States and for a given year. Therefore, the model may not be accurate for estimating Infant mortality rates for a different time, say historical values. This can be deduced from the fact that the model estimates the highest theoretical Infant Mortality Rate to be at 68 at zero values of independent variables. It can only be used to set policy targets based on the state of affairs of health infrastructure in 2015-16. Similarly, model cannot be used for times series forecasts.

4. The model uses single equation for all the 29 states. Patterns of health infrastructure and indicators vary across State. Different States have different issues in health care. Moreover, Health is a state subject. However, the model imposes a 'one-size fits all' approach. While a single model may be therefore not completely justified, but the model at the same time is able to explain the variations present in the data, and is therefore suitable for setting estimations of future values and targets to be achieved in individual indicators. Also model offers opportunity to compare the performances of States and give fixed targets for factors that can reduce Infant Mortality Rate.

4. The equation of the model gives us indications that maternal and infant health care interventions should be focused on two factors: 
* Better health care infrastructure, factored in by the Antenatal Care factor, which is indicative of the impact quality health care service have on Infant Mortality Rate;

* But more importantly, it is the gender development indicator which encompasses not only gender development, but also social progress marked by technological access and Information and Communication Technology interventions that can have significant impact on controlling major health issues such as Infant Mortality Rate.

Therefore, mere infrastructure creation may not have desired impact, until gender development indicators are given a boost to solve some of the major Reproductive and Child health care issues.

\section{DISCUSSION AND FINDINGS}

The two factors which determine the value of Infant Mortality Rate as per the model are 'Coverage of Antenatal care' and 'Increasing Use of Mobile amongst Women'.

1. Coverage of Antenatal Care is strongly correlated with higher registration of pregnancies, increasing institutional delivery, issuing Mother and Child Protection Card and ensuring adequate Post Natal Care. Due to high and positive correlation any progress made in such indicators would therefore improve coverage of Antenatal Care and therefore as per the model reduce Infant Mortality Rate. The coverage of Antenatal Care therefore, acts as an indicator or a proxy or a policy target to track progress in reducing Infant Mortality Rate. The model doesn't give the indicators for such variables owing to small number of data points at State level $(n=29)$, it gives indicators having high degree of correlation with these variables.

Regarding this limitations, two clarifications are important:

(i) Many States, especially in Northeast India don't have commensurate infrastructure, but low Infant Mortality Rate. In the $11^{\text {th }}$ Five Year Plan document of Northeast Council has highlighted that inadequate health facilities in the States is one of the impediments which needs additional thrust. The other problem faced by the people in the area is poor communication infrastructure and poor accessibility of water facilities by the rural masses ${ }^{9}$.

The anomaly is attributed to higher percentage and awareness of benefits of breastfeeding and Vitamin A rich food. Inclusion of Northeastern States, therefore distorts the model to some extent. However, the resultant model would be too Mainland-centric. Therefore, many analysed factors hold significant relation with Infant Mortality Rate, but to prevent selective sample of study, the Northeastern States weren't excluded.

(ii) There exists large variation in Infant Mortality and Healthcare Infrastructure levels amongst the Northeast State. Therefore, the study is not focusing solely on regional patterns as the region may have outliers or intra-regional variations.

(iii) The model can be made more accurate if we look into the indicators district wise. But unfortunately, lack of devolution of powers at district level and lack of autonomy in framing targets deters one to give district wise intervention targets, even for a State. Policy planning for health is primarily developed by State government over the framework established by Central Government. Therefore, setting district targets may not have utility in public policy.

Table 9: Correlation of Indicator in the model with Health Infrastructure and Service metrics

\begin{tabular}{|c|c|}
\hline Indicator & $\begin{array}{l}\text { Correlation with "Percentage } \\
\text { of Mothers who had at least } 4 \\
\text { antenatal care visits" }\end{array}$ \\
\hline Percentage Institutional Birth & 0.784 \\
\hline $\begin{array}{l}\text { Mothers who consumed iron } \\
\text { folic acid for } 100 \text { days or more } \\
\text { when they were pregnant }(\%)\end{array}$ & 0.748 \\
\hline $\begin{array}{l}\text { Mothers who received } \\
\text { postnatal care from a doctor/ } \\
\text { nurse/LHV/ANM/midwife/ } \\
\text { other health personnel within } \\
2 \text { days of delivery }(\%)\end{array}$ & 0.904 \\
\hline
\end{tabular}


2. Increasing Use of Mobile amongst Women: This factor represents more than just female empowerment. Firstly, the factor implies agency that a female has. It also implies digital penetration and digital literacy. It represents the independence, the rights and level of empowerment a women has.

The variable not only implies a right that a women has but also indicative of access to technology in the State and therefore, quality of infrastructure available in the region.

The factor displays high degree of correlation with various gender development indicators like female literacy, ability to take decisions in household and also whether one has faced domestic violence, and is therefore indicative of not sheer access to technology but to higher degree of literacy, independence and to be able to take decisions at household level.

Table 10: Correlation of Indicators in Model with other Gender Development Indicator

\begin{tabular}{ll}
\hline Indicator & $\begin{array}{l}\text { Correlation with "Percentage } \\
\text { of women having a mobile } \\
\text { phone that they themselves } \\
\text { use" }\end{array}$ \\
\hline $\begin{array}{l}\text { Female Literacy Rate } \\
\begin{array}{l}\text { Currently married women } \\
\text { who usually participate in } \\
\text { household decisions (\%) }\end{array}\end{array}$ & 0.843 \\
$\begin{array}{l}\text { Ever-married women who } \\
\text { have ever experienced } \\
\text { spousal violence (\%) }\end{array}$ & -0.58582 \\
\hline
\end{tabular}

3. Information and Communication Technology (ICT) solutions have multiple purposes in public health care management. Firstly, ICT can be leveraged for better targeting of welfare schemes, conditional cash transfers, as seen in Indian Government's JAM (Jan-Dhan, Aadhaar and Mobile) trinity push. Secondly, it offers opportunity for collecting health care data for better planning and policy making. Thirdly, ICT interventions are now also being used for Information, Education and Communication measure related to maternal health. 'Kilkari' App developed by Haryana State National Health Mission gives audio messages to registered mobile numbers on pregnancy, child and childbirth care every week from second trimester till the child is one year old. Lastly, ICT interventions can be used for capacity building in healthcare workers to reinforce and strengthen existing infrastructure. For instance, 'Suyojana' is an app developed by Karnataka State that improves decision making processes of Auxiliary Nurse Midwife (ANM) in rural areas.

\section{CLUSTERING STATES}

Different States are at different points on the curve, as far as reducing Infant Mortality Rates are concerned. States like Kerala have recorded single digit figures, while Uttar Pradesh, Madhya Pradesh have Infant Mortality Rate levels well above 50. Therefore the policy targets for different groups of states have to be different. For this purpose, the study classifies the States in four clusters: Achiever, Front Runner, Performer and Aspirant.

For the purpose of clustering, K-Mean method was applied. Here, since there are four clusters we take $K$ $=4$. The initial centroid of clusters was set at 7.5, 22.5, 37.5 and 52.5. Based on these centroids the States were divided into four clusters. A single iteration for K-Mean Algorithm was required.

\section{TARGET SETTING FOR CLUSTERS}

The final part of the study includes setting policy targets for different clusters based on the regression models. The targets are derived for individual factors are determined, and based on the value of factors target Infant Mortality Levels are determined. The below mentioned table gives us the cluster for which target is set, the clusters it is grouped with, the cut off percentile and the targets at the cut off percentile. Based on the cutoff target, estimated targets of Infant Mortality Rate are set up.

\section{CONCLUSION}

Infant Mortality Rate has been an important metric being tackled by State and National Governments under Reproductive and Child Health care programs. The inability of States to achieve national targets requires focusing on incremental targets rather than 
Table 11: Clusters of States and description

\begin{tabular}{|c|c|c|}
\hline Cluster & States & Comments \\
\hline Achiever & Goa, Kerala & $\begin{array}{l}\text { The States have very low levels of Infant Mortality Rate. The states perform } \\
\text { well on gender development indicators. Indicators indicate well developed } \\
\text { infrastructure and metrics. }\end{array}$ \\
\hline Front Runner & $\begin{array}{l}\text { Tamil Nadu, Manipur, Arunachal } \\
\text { Pradesh, Maharashtra, West Bengal, } \\
\text { Tripura, Karnataka, Telangana, Punjab, } \\
\text { Nagaland, Sikkim, Meghalaya }\end{array}$ & $\begin{array}{l}\text { The majority of States in the group have reduced IMR levels to below national } \\
\text { target of 28, barring four States, Punjab, Nagaland, Sikkim, Meghalaya which } \\
\text { have IMR levels just marginally above the target at 29-30. Such States have to } \\
\text { target to get IMR to below } 20 \text { levels. }\end{array}$ \\
\hline Performer & $\begin{array}{l}\text { Jammu \& Kashmir, Haryana, Gujarat, } \\
\text { Himachal Pradesh, Andhra Pradesh, } \\
\text { Odisha, Mizoram, Uttarakhand, } \\
\text { Rajasthan, Jharkhand }\end{array}$ & $\begin{array}{l}\text { Performer States are states that have registered historically high IMR rates, } \\
\text { but in last decade have substantially reduced IMR. However, since such } \\
\text { States have had high IMR levels, the current situations finds them at 5-15 } \\
\text { points higher than national average }\end{array}$ \\
\hline \multirow[t]{2}{*}{ Aspirant } & $\begin{array}{l}\text { Assam, Bihar, Madhya Pradesh, } \\
\text { Chhattisgarh, Uttar Pradesh }\end{array}$ & $\begin{array}{l}\text { Aspirant States have registered modest improvement in IMR and have had } \\
\text { extremely high levels of IMR in the Past. } 4 \text { of the } 5 \text { States were categorized as } \\
\text { "BIMARU" (Bihar, Madhya Pradesh, Rajasthan, Uttar Pradesh, Hindi word } \\
\text { for sick). }\end{array}$ \\
\hline & & $\begin{array}{l}\text { Such states are farthest from target and need to reduce IMR levels by } 20 \text { to } 30 \\
\text { points to achieve IMR targets. }\end{array}$ \\
\hline
\end{tabular}

Table 12: Clusters of States with respective indicator targets and estimated target Infant Mortality Rate

\begin{tabular}{llllll}
\hline Cluster & Grouped with & $\begin{array}{l}\text { Target based on } \\
\text { (Percentile) }\end{array}$ & $\begin{array}{l}\text { Female Mobile Phone } \\
\text { Coverage }\end{array}$ & $\begin{array}{l}\text { Percentage of women with at } \\
\text { least 4 Ante Natal Care }\end{array}$ & Target IMR \\
\hline Achiever & N.A & N.A & N.A target set & N.A & 16 \\
Front Runner & Achiever & $90^{\text {th }}$ & 80.57 & 86.66 & 24 \\
Performer & Achiever, Front Runner & $75^{\text {th }}$ & 65.85 & 75.325 & 30 \\
Aspirant & Achiever, Front Runner, & $60^{\text {th }}$ & 55.16 & 69.08 & \\
& Performer & & & & \\
\hline
\end{tabular}

expecting drastic reduction over medium term, say five years. Therefore, the proposed model offers some basic policy targets that are tracked on decennial basis under National Family Health Survey. The study recommends a few incremental steps that can help achieve targets for different indicators and in turn Infant Mortality Rate.

1. The first indicator such as providing at least four Antenatal Care visits entails improving coverage of Antenatal Care. Therefore to achieve the target States are recommended to:
(a) Increasing network and robust nature public healthcare infrastructure;
(b) Better registration of pregnancies; and
(c) Increasing capacity of healthcare workers;

(d) Develop management information systems to record and register new pregnancies

2. The second indicator of the study is what is actually unexpected and yet acknowledged by government decades back. Introduction of Reproductive and Child Health program in 1995 linked the reproductive wellbeing with feminist visions of women empowerment ${ }^{10}$. The indicator in itself is a combination of two key social changes a developing country aspires for. The indicator encapsulates Gender development, evident from its high correlation with gender development indices and also access to technology, especially in rural areas. The second policy target requires States to not only focus on classical means to empower women through education and employment but also 
improving digital literacy. The indicator therefore, in itself is a multidimensional output indicator encompassing female literacy, digital literacy and digital penetration. Therefore, to achieve better performance in this indicator following policy actions are recommended:

(a) Focus on improving better digital penetration by increasing subscriber base and increasing access to mobile technology.

(b) Initiating campaigns to increase digital literacy.

(c) Promoting more schemes which leverage technology to develop capacity of health workers and help in spreading awareness amongst pregnant women.

(d) Incentivizing more usage of mobile phones and agency to women by identifying them as beneficiaries in a household for various benefits, as we have seen in schemes such as Public Distribution System and Pradhan Mantri Awas Yojana.

Therefore, ICT solutions and focus on gender development indicators can be combined to meet other policy targets. The second indicator, 'Percentage of Women having mobile phone that they use themselves' is a point of convergence for Sustainable Development Goal 3- Good Health and Well Being (Reducing Infant Mortality Rate), Sustainable Development Goal 5Gender Equality (Enhancing Female Literacy and Access to technology) and Sustainable Development Goal 9Build resilient infrastructure, promoting inclusive and sustainable development (Increasing Digital Literacy, Digital Penetration).

'Information and communication technologies (ICTs) can help accelerate progress towards every single one of the 17 United Nations Sustainable Development Goals (SDGs) ${ }^{\prime 11}$.

\section{REFERENCES}

1. World Health Organization Indicator Metadata Registry List: Infant Mortality Rate (https://www.who.int/data/gho/ indicator-metadata-registry/imr-details/1)

2. National Health Policy, Ministry of Health and Family Welfare, Government of India 2017.

3. Sample Registration System Bulletin, Office of Registrar General, Ministry of Home Affairs, Government of India published in May 2020, and Reference Year 2018.

4. SDG India Index, Niti Aayog 2019.

5. 'Rajasthan no longer a BIMARU State' The Hindu Business line Jan 23, 2015 (https://www.thehindubusinessline. com/news/national/rajasthan-no-longer-bimaru-state/ article6815198.ece)

6. Mishra S, Mohanty K.S., 'Out of pocket expenditure and distress financing on institutional delivery in India', International Journal for Equity in Health, June 2019.

7. Gupta S.K. Dinesh K.P., et al. 'Impact of Janani Suraksha Yojana on Institutional Delivery Rate and Maternal Morbidity and Mortality: An Observational Study' in Journal of Health, Population and Nutrition Dec. 2012.

8. Kumar R., 'Gender in Reproductive and Child HealthPolicy', Economic and Political Weekly 2002.

9. Lalneizo D. \& Reddy S., 'Health status of children in North Eastern States of India', Indian Anthropologist, 2010.

10. Kumar R., 'Gender in Reproductive and Child Health Policy', Economic and Political Weekly 2002.

11. Backgrounder prepared for the International Telecommunications Union Plenipotentiary 2018 Conference, Abu Dhabi. 